\title{
Canadian study fuels move to limit rise in drug prices
}

Quebec. The Canadian government body charged with holding down the cost of patented drugs is proposing amendments to its pricing guidelines at the same time a study shows that Canadian prices are often higher than the international median. The Canadian parliament recently extended patent protection after pharmaceutical companies promised to control prices and to increase their spending on research into new drugs.

A new study by the Patented Medicine Prices Review Board (PMPRB) found that 56 per cent of the introductory prices of 124 new drugs in Canada were greater than the corresponding median international prices. And the most popular drugs were more expensive in Canada than in any other country listed in the Patented Medicines Regulations except the United States and Germany. The Canadian analysis confirmed the findings of a recent US General Accounting Office study that found prices for the same drug to be higher in the United States than in Canada.

The study found that the less useful the new product, the more the Canadian drug companies charged for it. Prices were higher in 21 per cent of cases involving drugs that provide moderate, little or no improvement over comparable medicines, but in only 9 per cent of cases involving therapeutic breakthroughs or drugs providing substantial improvement. Among products providing new strengths or a comparable dosage of an existing medicine, only 5 per cent had higher Canadian prices.

The board found that 105 of 177 drug products sold in Canada were priced above

\section{Zeneca increases research spending}

London. The various business that will make up Zeneca, the new company being created out of the biosciences activities of Britain's Imperial Chemical Industries (ICI), spent $£ 457$ million (US $\$ 640$ million) on research and development last year, according to figures released last week in preparation for the company's stock market launch in June.

This figure represents 11 per cent of the company's total sales and is an increase of 9.8 per cent over R\&D spending in 1991. In contrast, growth in R\&D spending between 1990 and 1991 was only 5 per cent, largely as a result of a rationalization of research on agrochemicals. Peter Doyle, formerly research and technology director of ICI who is to become an executive director of Zeneca, estimates that 1993 spending is likely to rise to "just under $£ 500$ million".

D.D. the median international price. In 42 cases the Canadian price was the highest in the world.

Patent drug prices have been under intense scrutiny in Canada since 1987 when parliament approved an extension to the patent act that critics warned would lead to higher drug prices. Brand-name pharmaceutical companies denied that this would happen and promised greater investments in research in return for longer patent protection.

The price review board was set up as a result of the new patent legislation. It has found that between 1987 and 1991, the price of existing patented drugs increased by 2.9 per cent compared with an increase of 4.7 per cent permitted by the guidelines, and that the annual increase has consistently remained below the rate of inflation.

In return for the 1987 extension, patent drug companies promised to raise their research spending over the next ten years from 4.9 per cent of sales to 10 per cent. In October 1991, the Pharmaceutical Manufacturers' Association of Canada (PMAC) said that 47 of its 67 members were spending 10.1 per cent of their sales on research, a total of $\$ 301$ million.

Last month, the government passed legislation extending market exclusivity for most patent drugs for another three years and modifying Canada's system of 'compulsory licensing', which makes it relatively easy for generic drug companies to copy brand-name products (see Nature 359, $351 ; 1992)$. In lobbying for the law, the brand-name manufacturers announced that their research spending exceeded $\$ 400$ million a year.

The revelation that Canadian prices for new drugs are relatively high internationally has become a political issue. "Something is wrong here", says New Democratic Party leader Audrey McLaughlin. But PMAC's financial officer, Robert Livingstone, says that drug prices depend on many factors, including the type of national health system through which they are marketed, and that meaningful comparisons are difficult. "We have not yet been able to review the data", he says. "We are committed to fair and reasonable prices, but what is fair and reasonable?"

Last autumn, the price board proposed amendments that, among other things, would limit the price of a new drug that provides moderate or no improvement over existing drugs to the median international price or the price of all drugs in that category. Hearings on the proposals were held in February, and the board is expected to make a final decision in June.

\section{5 drug companies to share data on AIDS therapies}

Washington. In a break with tradition, 15 pharmaceutical companies from the United States and Europe last week announced an agreement to work together on combination drug therapies to fight the human immunodeficiency virus (HIV). The participating companies will share information and supplies of drugs early in the drug development process to carry out independent testing of promising combinations of new drugs. The collaboration, which includes an effort to standardize preclinical testing procedures, does not extend to the search for an AIDS vaccine nor to basic research on the disease.

A recent survey by the US Pharmaceutical Manufacturers Association reported that more than 90 medicines were being developed to combat AIDS and AIDS-related conditions. But progress has been hindered by problems with toxicity and with the ability of HIV to become resistant to individual drugs. Earlier this month, preliminary results from an Anglo-French trial cast doubt on the ability of AZT (azidothymidine) to delay the onset of AIDS in patients with HIV (see Nature 362, 483; 1993).

A year in the making, the agreement was conceived by P. Roy Vagelos, chairman and chief executive officer of Merck, and Edward Scolnick, president of Merck Research Laboratories, with strong support from Juergen Drews of Hoffmann-La Roche. Participants in the Inter-Company Collaboration for AIDS Drug Development will share relevant information and supplies when a drug reaches phase II clinical testing, the point at which the drug's safety profile is known and preliminary tests are under way on efficacy.

Participants must be actively involved in AIDS antiviral research and have an investigational new drug in the early stages of drug development. By dealing with work done before a product is ready for market, the collaboration hopes to avoid violating US antitrust laws and other problems associated with intellectual property rights and the sharing of royalties.

Although most of the important companies have signed up, two notable absentees are Abbott Laboratories and Upjohn. A spokesperson for Upjohn says that the company prefers to maintain an independent anti-AIDS programme, which now receives more than a fifth of the corporate budget for drug discovery research.

The participating companies, nine of which are from the United States, include AB Astra, Boehringer Ingelheim, BristolMyers Squibb, Burroughs Welcome, Du Pont-Merck, Eli Lilly, Glaxo, Hoechst AG, Hoffmann-La Roche, Merck, Miles, Pfizer, Sigma Tau, SmithKline Beecham and Syntex.

Diane Gershon 